S2 File. Overview of the synthesis of T3-1

( $N$-(8-fluoro-6-(pyridin-4-yl)imidazo[1,2-a]pyridin-2-yl)-4-(2-methyl-1-(4-methylpiperazin1-yl)-1-oxopropan-2-yl)benzamide trihydrochloride)<smiles>CC(C)(C)C(=O)Nc1cn2cc(Br)cc(F)c2n1</smiles><smiles>[Y20]C(C)(C)C(=O)Nc1cn2cc(Br)cc(F)c2n1</smiles><smiles>CN1CCN(C(=O)C(C)(C)c2ccc(C(=O)Nc3cn4cc(-c5ccncc5)cc(F)c4n3)cc2)CC1</smiles>

Reagents and conditions: a. i) $p$-toluenesulfonyl chloride, pyridine; ii) $\mathrm{NaOH}$; b. iodoacetamide, $\mathrm{N}, \mathrm{N}$-diisopropylethylamine; c. trifluoroacetic anhydride; d. HCl; e. i) 4-(1-methoxy-2-methyl-1oxopropan-2-yl)benzoic acid, oxalyl chloride, $N, N$-dimethylformamide; f. i) 4-(4,4,5,5tetramethyl-1,3,2-dioxaborolan-2-yl)pyridine, [1,1'-bis(diphenylphosphino)ferrocene]palladium (II) dichloride dichloromethane adduct, cesium carbonate; ii) NaOH; g. 1-methylpiperazine, 1[Bis(dimethylamino)methylene]-1H-1,2,3-triazolo[4,5-b]pyridinium 3-oxide hexafluorophosphate, $N, N$-diisopropylethylamine.

\title{
Synthesis of T3-1 (14)
}<smiles>CNc1ncc(Br)cc1F</smiles>

\section{8: $N$-(5-bromo-3-fluoropyridin-2-yl)-4-methyl- $N$-tosylbenzenesulfonamide}

To a solution of 5-bromo-3-fluoropyridin-2-amine (compound 7 in Fig. S2, 8.8 g, 46.07 mmol) in anhydrous pyridine $(100 \mathrm{ml}), p$-toluenesulfonyl chloride was slowly added (17.56 g, $92.15 \mathrm{mmol})$ at $0^{\circ} \mathrm{C}$. The reaction mixture was then heated at $90^{\circ} \mathrm{C}$ for $16 \mathrm{~h}$. Pyridine was removed under reduced pressure to afford the crude product. To a solution of this product in a solution of methanol $(300 \mathrm{ml})$ and water $(50 \mathrm{ml})$ was added $\mathrm{NaOH}(7.4 \mathrm{~g}$ in $25 \mathrm{ml}$ of water). The reaction mixture was stirred at room temperature for $3 \mathrm{~h}$. Methanol was removed under reduced pressure. 
The residue was diluted with water and adjusted to $\mathrm{pH} \sim 5-6$ with $1 \mathrm{~N} \mathrm{HCl}$. The mixture was then extracted with AcOEt. The organic layer was washed with water, brine, dried over sodium sulfate, and concentrated to give the title compound $(15.0 \mathrm{~g}, 94 \%)$.

${ }^{1} \mathrm{H}-\mathrm{NMR}$ (DMSO- $\left.d_{6}\right): \delta: 2.28$ (3H, s), $7.13(2 \mathrm{H}, \mathrm{d}, J=8.0 \mathrm{~Hz}), 7.35(1 \mathrm{H}, \mathrm{dd}, J=10.4,2.0 \mathrm{~Hz}$ ), 7.62-7.67 (3H, m).<smiles>NC(=O)Cn1cc(Br)cc(F)c1=[W]</smiles>

\section{9: 2-(5-bromo-3-fluoro-2-(tosylimino)pyridin-1(2H)-yl)acetamide}

To a solution of $8(13.8 \mathrm{~g}, 40.0 \mathrm{mmol})$ in dry $N, N$-dimethylformamide $(150 \mathrm{ml})$ was added $N, N$ diisopropylethylamine $(15.48 \mathrm{~g}, 120.0 \mathrm{mmol})$ and iodoacetamide $(14.8 \mathrm{~g}, 40.0 \mathrm{mmol})$. The mixture was stirred at room temperature for one day. This reaction mixture was diluted with water, and extracted with AcOEt. The organic layer was washed with sat. ammonium chloride solution, brine, dried over magnesium sulfate and concentrated to obtain the crude product that was then chromatographed on $\mathrm{SiO}_{2}$ with AcOEt to afford the title compound (11.94 g, 74\%).

${ }^{1} \mathrm{H}-\mathrm{NMR}\left(\mathrm{DMSO}-d_{6}\right) \delta: 2.42(3 \mathrm{H}, \mathrm{s}), 4.15(2 \mathrm{H}, \mathrm{s}), 7.06(1 \mathrm{H}, \mathrm{s}), 7.40-7.44(3 \mathrm{H}, \mathrm{m}), 7.55(2 \mathrm{H}, \mathrm{d}$, $J=8.4 \mathrm{~Hz}), 8.34-8.36(2 \mathrm{H}, \mathrm{m})$.

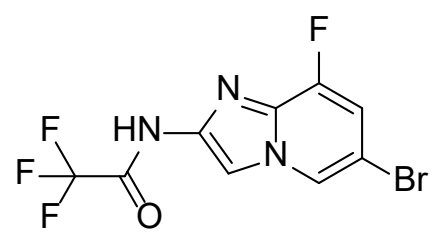

10: N-(6-bromo-8-fluoroimidazo[1,2-a]pyridin-2-yl)-2,2,2-trifluoroacetamide

A suspension of $9(11.94 \mathrm{~g}, 29.7 \mathrm{mmol})$ in a mixture of dichloromethane $(150 \mathrm{ml})$ and trifluoroacetic anhydride $(80 \mathrm{ml})$ was heated at reflux for $3 \mathrm{~h}$. The solvent was removed under reduced pressure and the residue partitioned between AcOEt and sat. $\mathrm{NaHCO}_{3}$ solution. The organic layer was washed with $1 \mathrm{~N} \mathrm{HCl}$, water and brine, and dried over $\mathrm{Na}_{2} \mathrm{SO}_{4}$. The solvent was removed under reduced pressure and the residue was washed with ether to afford the title compound (5.85 g, 60\%).

${ }^{1} \mathrm{H}-\mathrm{NMR}\left(\mathrm{DMSO}-d_{6}\right) \delta: 7.54(1 \mathrm{H}, \mathrm{d}, J=10.4 \mathrm{~Hz}), 7.73(1 \mathrm{H}, \mathrm{s}), 8.62(1 \mathrm{H}, \mathrm{s}), 11.75(1 \mathrm{H}, \mathrm{brs})$. 


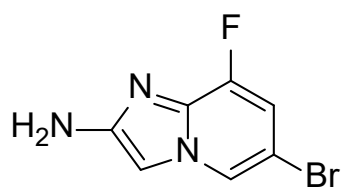

\section{1: 6-bromo-8-fluoroimidazo[1,2-a]pyridin-2-amine}

To a suspension of $\mathbf{1 0}(2 \mathrm{~g}, 6.13 \mathrm{mmol})$ in methanol $(45 \mathrm{ml})$ was added $2 \mathrm{~N} \mathrm{HCl}(15.34 \mathrm{ml}, 30.67$ mmol). The mixture was stirred at $50^{\circ} \mathrm{C}$ for $2 \mathrm{~h}$. The mixture was neutralized with $2 \mathrm{~N} \mathrm{NaOH}(14$ $\mathrm{ml}$ ) to ca. $\mathrm{pH}$ 7. The mixture was then concentrated, and the residue partitioned between AcOEt and aqueous $\mathrm{NaHCO}_{3}$. The aqueous layer was extracted with AcOEt. Combined organic layers were washed with brine, and concentrated. The residue was triturated with a mixed solution of AcOEt, ether and hexane to give the title compound (1.20 g, 85\%).

${ }^{1} \mathrm{H}-\mathrm{NMR}\left(\mathrm{DMSO}-d_{6}\right) \delta: 5.42(2 \mathrm{H}, \mathrm{s}), 6.87(1 \mathrm{H}, \mathrm{s}), 7.11(1 \mathrm{H}, \mathrm{dd}, J=11.0,1.5 \mathrm{~Hz}), 8.23(1 \mathrm{H}, \mathrm{d}, J$ $=1.5 \mathrm{~Hz})$.

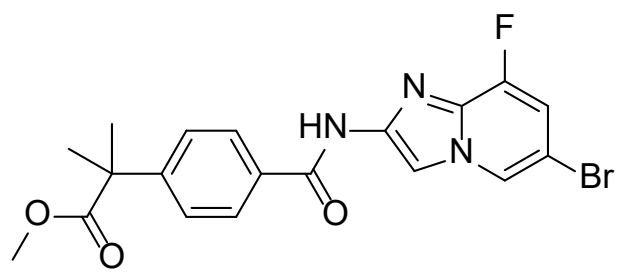

12: methyl 2-(4-((6-bromo-8-fluoroimidazo[1,2-a]pyridin-2-yl)carbamoyl)phenyl)-2methylpropanoate

To a solution of 4-(1-methoxy-2-methyl-1-oxopropan-2-yl)benzoic acid (319 mg, $1.43 \mathrm{mmol}$ ) in dry tetrahydrofuran $(5 \mathrm{ml})$ was added oxalyl chloride $(0.137 \mathrm{ml}, 1.56 \mathrm{mmol})$ and catalytic amounts of $\mathrm{N}, \mathrm{N}$-dimethylformamide. The mixture was stirred at room temperature for $1 \mathrm{~h}$ followed by azeotropic concentration with toluene $(5 \mathrm{ml})$ to give the corresponding acid chloride. To a solution of the acid chloride in $N, N$-dimethylacetamide $(5 \mathrm{ml})$ was added 11 (300 $\mathrm{mg}, 1.30 \mathrm{mmol})$. The mixture was stirred at room temperature for $3 \mathrm{~h}$. The mixture was partitioned between AcOEt and water. The aqueous layer was extracted with AcOEt. The combined organic layers were washed with brine and concentrated. The residue was chromatographed on $\mathrm{NH}-\mathrm{SiO}_{2}$ with $\mathrm{AcOEt} /$ hexane and triturated with ether to give the title compound (544 mg, 96\%).

${ }^{1} \mathrm{H}-\mathrm{NMR}\left(\mathrm{DMSO}-d_{6}\right) \delta: 1.56(6 \mathrm{H}, \mathrm{s}), 3.62(3 \mathrm{H}, \mathrm{s}), 7.46-7.54(3 \mathrm{H}, \mathrm{m}), 7.68(1 \mathrm{H}, \mathrm{s}), 8.03(2 \mathrm{H}, \mathrm{d}$, $J=8.4 \mathrm{~Hz}), 8.50(1 \mathrm{H}, \mathrm{d}, J=1.4 \mathrm{~Hz}), 10.65(1 \mathrm{H}, \mathrm{s})$. 


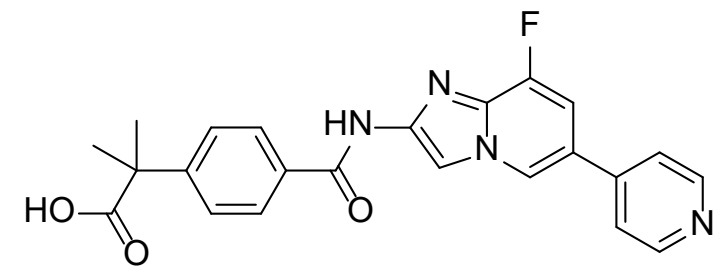

13:

2-(4-((8-fluoro-6-(pyridin-4-yl)imidazo[1,2-a]pyridin-2-yl)carbamoyl)phenyl)-2methylpropanoic acid

A mixture of 12 (565 mg, $1.30 \mathrm{mmol})$, 4-(4,4,5,5-tetramethyl-1,3,2-dioxaborolan-2-yl)pyridine (400 mg, $1.95 \mathrm{mmol})$, cesium carbonate $(635 \mathrm{mg}, 1.95 \mathrm{mmol})$ and [1,1'bis(diphenylphosphino)ferrocene]palladium(II) dichloride dichloromethane adduct (106 mg, 0.13 mmol) in 1,2-dimethoxyethane $(5 \mathrm{ml})$ and water $(0.5 \mathrm{ml})$ was stirred at $100^{\circ} \mathrm{C}$ under microwave irradiation for $1 \mathrm{~h}$. The mixture was partitioned between AcOEt and water. The aqueous layer was extracted with AcOEt. The combined organic layers were washed with brine, and passed through a NH-SiO 2 pad ( $2 \mathrm{~g}$, eluent: $10 \% \mathrm{MeOH} / \mathrm{EtOAc})$. The filtrate was concentrated, and the residue was triturated with ether to give crude methyl 2-(4-((8-fluoro-6-(pyridin-4-yl)imidazo[1,2a]pyridin-2-yl)carbamoyl)phenyl)-2-methylpropanoate. To a solution of the crude product in methanol $(5 \mathrm{ml})$ and tetrahydrofuran $(2.5 \mathrm{ml})$ was added $2 \mathrm{~N} \mathrm{NaOH}(1.95 \mathrm{ml}, 3.90 \mathrm{mmol})$. The mixture was stirred at $50^{\circ} \mathrm{C}$ for $8 \mathrm{~h}$. The mixture was neutralized with $2 \mathrm{~N} \mathrm{HCl}$ and extracted with AcOEt. The combined organic layers were washed with brine, dried over $\mathrm{Na}_{2} \mathrm{SO}_{4}$, and concentrated. The solidified residue was triturated with ether to give the title compound (402 mg, $74 \%)$.

${ }^{1} \mathrm{H}-\mathrm{NMR}\left(\mathrm{DMSO}-d_{6}\right) \delta: 1.54(6 \mathrm{H}, \mathrm{s}), 7.55(2 \mathrm{H}, \mathrm{d}, J=8.5 \mathrm{~Hz}), 7.71-7.79(2 \mathrm{H}, \mathrm{m}), 7.80-7.86(2 \mathrm{H}$, m), $8.06(2 \mathrm{H}, \mathrm{d}, J=8.3 \mathrm{~Hz}), 8.61-8.68(3 \mathrm{H}, \mathrm{m}), 10.70(1 \mathrm{H}, \mathrm{s}), 12.48(1 \mathrm{H}, \mathrm{brs})$.

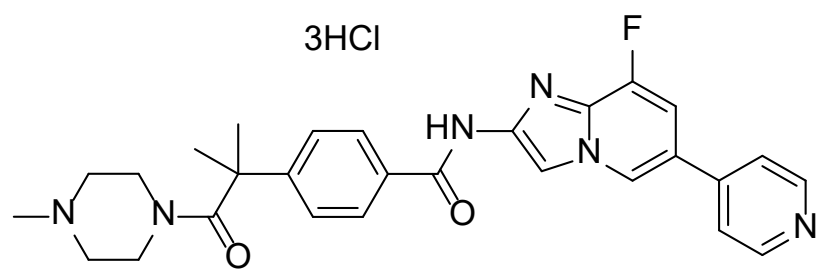

14 (T3-1): $\quad$-(8-fluoro-6-(pyridin-4-yl)imidazo[1,2-a]pyridin-2-yl)-4-(2-methyl-1-(4methylpiperazin-1-yl)-1-oxopropan-2-yl)benzamide trihydrochloride

To a mixture of 13 (120 mg, $0.29 \mathrm{mmol}$ ), 1-[bis(dimethylamino)methylene]-1H-1,2,3triazolo[4,5-b]pyridinium 3-oxide hexafluorophosphate (164 mg, $0.43 \mathrm{mmol}), \quad \mathrm{N}, \mathrm{N}$ diisopropylethylamine $(0.100 \mathrm{ml}, 0.57 \mathrm{mmol})$ and $N, N$-dimethylacetamide $(4 \mathrm{ml})$ was added 1 methylpiperazine $(0.048 \mathrm{ml}, 0.43 \mathrm{mmol})$. The mixture was stirred at room temperature for $2 \mathrm{~h}$. The mixture was partitioned between AcOEt and brine. The aqueous layer was extracted with 
AcOEt. The combined organic layers were washed with brine, and concentrated. The residue was chromatographed on $\mathrm{SiO}_{2}$ with methanol/AcOEt to give the compound in free form. This product was dissolved in ethanol $(2.5 \mathrm{ml})$, and to the resulting solution was added $4 \mathrm{~N} \mathrm{HCl}$ in AcOEt $(0.5$ $\mathrm{ml}$ ) followed by addition of ether ( $3 \mathrm{ml}$ ) to give the title compound (99 $\mathrm{mg}, 57 \%$ ).

${ }^{1} \mathrm{H}-\mathrm{NMR}\left(\mathrm{DMSO}-d_{6}\right) \delta: 1.51(6 \mathrm{H}, \mathrm{s}), 2.69(3 \mathrm{H}, \mathrm{d}, J=3.7 \mathrm{~Hz}), 2.71-3.39(8 \mathrm{H}, \mathrm{m}), 7.43(2 \mathrm{H}, \mathrm{d}, J$ $=8.4 \mathrm{~Hz}), 7.81(1 \mathrm{H}, \mathrm{s}), 7.96(1 \mathrm{H}, \mathrm{dd}, J=12.5,1.2 \mathrm{~Hz}), 8.17(2 \mathrm{H}, \mathrm{d}, J=8.4 \mathrm{~Hz}), 8.38(2 \mathrm{H}, \mathrm{d}, J=$ $6.3 \mathrm{~Hz}), 8.93(2 \mathrm{H}, \mathrm{d}, J=6.7 \mathrm{~Hz}), 9.04(1 \mathrm{H}, \mathrm{d}, J=1.1 \mathrm{~Hz}), 10.98(1 \mathrm{H}, \mathrm{s}), 11.03(1 \mathrm{H}$, brs $)$. 